\title{
ENDOCRINOLOGICAL EFFECTS OF EXPERIMENTALLY INDUCED EXTRA-UTERINE PREGNANCIES IN VIRGIN MICE*
}

\author{
D. R. S. KIRBY \\ Department of Zoology, University of Oxford
}

(Received 15th February 1965)

\begin{abstract}
Summary. Experimentally induced extra-uterine pregnancies (EUP) in virgin mice did not stop the oestrous cycle, inhibit mating with ensuing pregnancy or stimulate the corpora lutea sufficiently to produce progestational changes in the genital tract. The EUP, however, caused changes typically associated with pregnancy in the adrenal cortex and mammary glands. In the former the X-zone either completely disappeared or underwent degenerative changes. The mammary glands showed definite lobulo-alveolar development, not affected by adrenalectomy, but abolished both by ovariectomy and hypophysectomy.
\end{abstract}

\section{INTRODUGTION}

The mouse blastocyst will implant in a wide range of extra-uterine sites and will form trophoblast and also, in a proportion of cases, morphologically normal embryos. Earlier experiments have shown that the endocrinological state of the host mouse did not influence the development of the transplanted blastocyst. Thus normal development of the conceptus, especially its placental component, will occur in males, and pregnant and non-pregnant females (Kirby, 1962). The process is unaffected by hypophysectomy, ovariectomy or adrenalectomy.

The experiments presented here were designed to detect any reciprocal stimulation by the extra-uterine pregnancy of the host mouse.

\section{General procedures}

\section{MATERIALS AND METHODS}

The experiments were performed on young, sexually mature, virgin Swiss white mice. The mice were not strictly inbred but were obtained from a population which had been 'closed' for 17 years. Vaginal smears were taken daily and only mice which showed a regular oestrous cycle were selected for experimental purposes.

All blastocysts were obtained from the uteri of donor mice $3 \frac{1}{2}$ days after the appearance of the vaginal plug. They were then transplanted (one or two to each mouse) to the kidney or to the spleen using the techniques described

* Presented at the Society for the Study of Fertility Annual Conference, 1963.

$D^{*}$

403 
elsewhere (Kirby, 1962, 1963). On the day of transplantation, roughly equal numbers of host mice at each stage of the oestrous cycle were represented. After transplantation the vaginal smear was recorded daily until autopsy, usually a period between 9 and 11 days.

\section{Traumatization of the uterus}

Traumatization of the uterus was performed 3 or 4 days after the transplantation of the blastocyst, by inserting a thread transversely through the uterine wall. The uterus was inspected for a decidual reaction at autopsy 8 days later. In case of doubt the traumatized portion of uterus was examined histologically.

\section{Ovariectomy with and without replacement therapy}

The mice were ovariectomized immediately before the blastocysts were transplanted. In a number of experiments this procedure was followed by the daily subcutaneous administration of $0.055 \mu \mathrm{g}$ oestrone in sesame oil, in order to maintain normal mammary duct growth (Flux, 1954).

\section{Adrenalectomy}

Adrenalectomy was performed immediately before transplantation of the blastocyst. The mice were given $1 \%$ saline solution in place of drinking water.

\section{Hypophysectomy}

Hypophysectomy was performed approximately 4 days before transplantation of the blastocysts. By the parapharyngeal route the hypophysis was exposed with a dental burr and the gland removed by aspiration. The procedure was greatly facilitated by the use of curved glass retractors connected to pot magnets by a short length of polythene tubing. The required tension of the retractors could be obtained simply by moving the magnets on the metal operating board. More powerful magnets were modified to secure the mouse for operating (Kirby, 1965).

At autopsy the complete head was decalcified and the sella turcica sectioned at $10 \mu$ to verify the complete removal of the hypophysis.

\section{Extra-uterine pregnancy with contemporary mating}

The mice were caged with proven males 5 days after the blastocyst had been transplanted to the kidney by which time it should be well established. They were examined daily for vaginal plugs during the next 5 days after which the males were removed. The mice that had mated were autopsied 8 days after the appearance of the vaginal plug to check for pregnancy. Any mouse in which the extra-uterine blastocyst had failed to develop was ignored.

\section{Transplantation of blastocysts to pseudopregnant hosts}

Host mice were rendered pseudopregnant by mating with vasectomized males. Uterine blastocysts were transplanted to the kidney 3 days after the appearance of the vaginal plug. Assuming that implantation of the transplanted blastocysts will be retarded by approximately $1 \frac{1}{2}$ days (Kirby, 1963), it should 
then occur at $4 \frac{1}{2}$ days post coitum, which corresponds with the time of uterine implantation.

\section{Histological methods}

For general histological examination the tissues were fixed in Zenker's fluid, dehydrated, then embedded, sectioned at $8 \mu$ and stained in Haematal ' 8 ' (Baker, 1962) and counterstained in Biebrich scarlet. In order to demonstrate the amount of lipid contained by the corpora lutea the ovaries were fixed in formol calcium (neutralized with marble chips), post-chromed in potassium dichromate for $25 \mathrm{hr}$ at $36^{\circ} \mathrm{C}$, washed, embedded and sectioned on a freezing microtome at $10 \mu$. The sections were stained in Nile Blue, Oil Red or, more usually, Sudan Black.

Whole mounts were made of the left and right inguinal (No. 4) mammary glands. The glands were exposed, fixed in situ in Bouin's fluid, removed, washed, stained in saturated aceto-carmine in $45 \%$ acetic acid, differentiated in $1 \%$ acetic acid, cleared and mounted.

The sizes of the corpora lutea were obtained by measuring with a calibrated graticule eyepiece two diameters at right angles to one another at the maximum area in section. The mean of these figures gives the mean diameter expressed in microns. The same technique was employed for measuring the individual luteal cells.

\section{RESULTS}

The development of a mouse blastocyst when transplanted to kidney or spleen has been described in detail elsewhere (Kirby, 1962, 1963). In both sites the blastocysts give rise to a mass of trophoblast which invades the host organ and occasionally becomes organized into a structure almost identical with a normal placenta (Pl. 1, Fig. 1). In some grafts, especially on the kidney, the embryo also develops and may be morphologically normal. In no case did grafts containing an embryo and trophoblast differ, as far as their endocrinological effects on the host were concerned, from those containing only trophoblast.

\section{Vaginal smears}

In only four of thirty-eight mice bearing an EUP was the vaginal cycle arrested, although in the majority of cases it was disturbed for 2 or 3 days post-operatively (see Table 1). In the eight control mice, on which a blank operation was performed, there was also disturbance of the vaginal smear cycle for a short time and in two of these mice the cycle was arrested. Both the control and experimental animals, in which the cycle was arrested, remained in dioestrus and showed no signs of vaginal mucification normally associated with pregnancy. In thirty of the thirty-eight animals bearing an EuP the condition of the vaginal epithelium at autopsy was confirmed by histological examination.

\section{Corpora lutea}

The measurements obtained from the ovaries of control animals showed that the maximum mean diameter of corpora lutea of ovulation was $650 \mu$, with individual luteal cells of $12 \mu$. The corresponding minimum figures for corpora 
lutea of pregnancy which had been stimulated for a period equivalent to the gestational age of the EUP were 850 and $18 \mu$ respectively (Pl. 1, Fig. 5). In no case did the size of the corpora lutea or the individual luteal cells of mice bearing an EUP exceed the measurements obtained for the corpora lutea of ovulation (see Table 1 and Pl. 1, Fig. 4).

The lipid content of the luteal cells as well as their size and vascularization have been used to differentiate between functional and non-functional corpora lutea (Deanesly, 1930; Chester Jones, 1952). Non-functional corpora lutea of ovulation contain abundant, coarse lipid, whereas the functional corpora

TABLE 1

TO SHOW EFFEGT OF AN EXTRA-UTERINE PREGNANGY

\begin{tabular}{l|c|c|c|c|c|c}
\hline \multicolumn{1}{|c|}{ Experiment } & $\begin{array}{c}\text { No. of } \\
\text { experiments }\end{array}$ & $\begin{array}{c}\text { No. with } \\
\text { extra- } \\
\text { uterine } \\
\text { pregnancies }\end{array}$ & $\begin{array}{c}\text { Vaginal } \\
\text { epithelium: } \\
\text { oestrus cycle } \\
\text { arrested }\end{array}$ & $\begin{array}{c}\text { Ovary: } \\
\text { corpora- } \\
\text { lutea } \\
\text { enlarged }\end{array}$ & $\begin{array}{c}\text { Uterus: } \\
\text { decidual } \\
\text { reaction } \\
\text { elicited }\end{array}$ & $\begin{array}{c}\text { Adrenal: } \\
\begin{array}{c}X-z o n e \\
\text { degenerated }\end{array}\end{array}$ \\
\hline $\begin{array}{l}\text { One or two } \\
\text { blastocysts } \\
\text { transplanted } \\
\text { to kidney }\end{array}$ & 36 & 30 & 4 & 0 & $0 *$ & $26 \dagger$ \\
$\begin{array}{l}\text { 'Blank' oper- } \\
\text { ation to } \\
\text { kidney } \\
\text { (control) }\end{array}$ & 8 & - & 2 & 0 & 0 & 0 \\
\hline $\begin{array}{l}\text { One blasto- } \\
\text { cyst trans- } \\
\text { planted to } \\
\text { spleen }\end{array}$ & 20 & 8 & 0 & 0 & - & 7 \\
$\begin{array}{l}\text { 'Blank' oper- } \\
\text { ation to spleen } \\
\text { (control) }\end{array}$ & 3 & - & 0 & 0 & - & 0 \\
\hline
\end{tabular}

* Uterus traumatized in fourteen mice only. $†$ Not checked in four mice.

lutea contain less abundant, finely distributed lipid. The ovaries of control animals showed considerable variation but, in general, confirmed the findings of previous workers. Similarly the ovaries of mice bearing an EUP showed variation in the lipid content of the corpora lutea, but in none was the staining reaction with Sudan Black typical of a corpus luteum of pregnancy.

\section{Endometrial response}

An attempt to produce a decidual reaction was made in fourteen of the thirty mice bearing an EUP on the kidney. In no case did the traumatization of the uterus result in a decidual reaction (Table 1 ). In the great majority macroscopic examination left no doubt of the result. In two cases, where there was a suspicion of a slight swelling, the traumatized portion of the uterus was histologically examined. No decidual tissue was present.

Extra-uterine pregnancy with contemporary mating

Of the fourteen mice caged with males while bearing an EUP, ten mated within 5 days of pairing. At autopsy seven of these mice were pregnant with an average of seven young per litter. 
PLATE 1

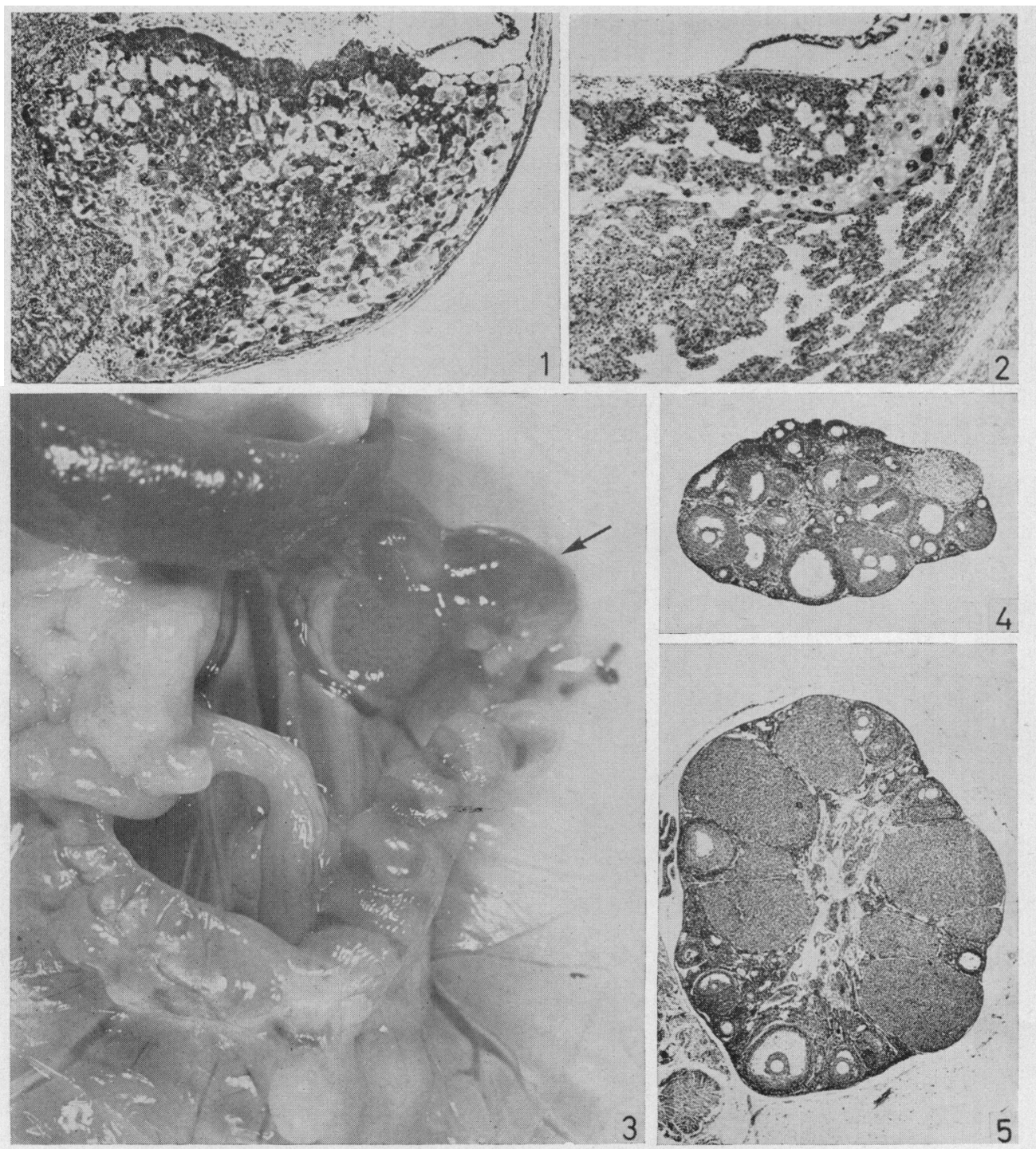

FIG. 1. Section of an extra-uterine 'placenta' developing on the kidney (left). The trophoblast has become organized into a structure which in gross and detailed appearance and in size is very similar to a normal placenta. Compare with Fig. $2 . \times 26$.

FIg. 2. Section through a normal placenta from a 10-day pregnant mouse. $\times 26$.

FIG. 3. Mouse with both an extra-uterine pregnancy (arrowed) and an intra-uterine pregnancy. The mouse was mated 7 days after a blastocyst had been transplanted beneath the kidney capsule, at which time the trophoblast would be well-developed and actively invading the host organ. $\times 4$.

Fig. 4. Section of an ovary removed at autopsy from a mouse bearing a flourishing extra-uterine pregnancy. Note that the corpora lutea (upper right) are small and apparently unstimulated. $\times 22$.

FIG. 5. Section of a 7-day pregnant mouse ovary showing large functional corpora lutea. $\times 22$. 


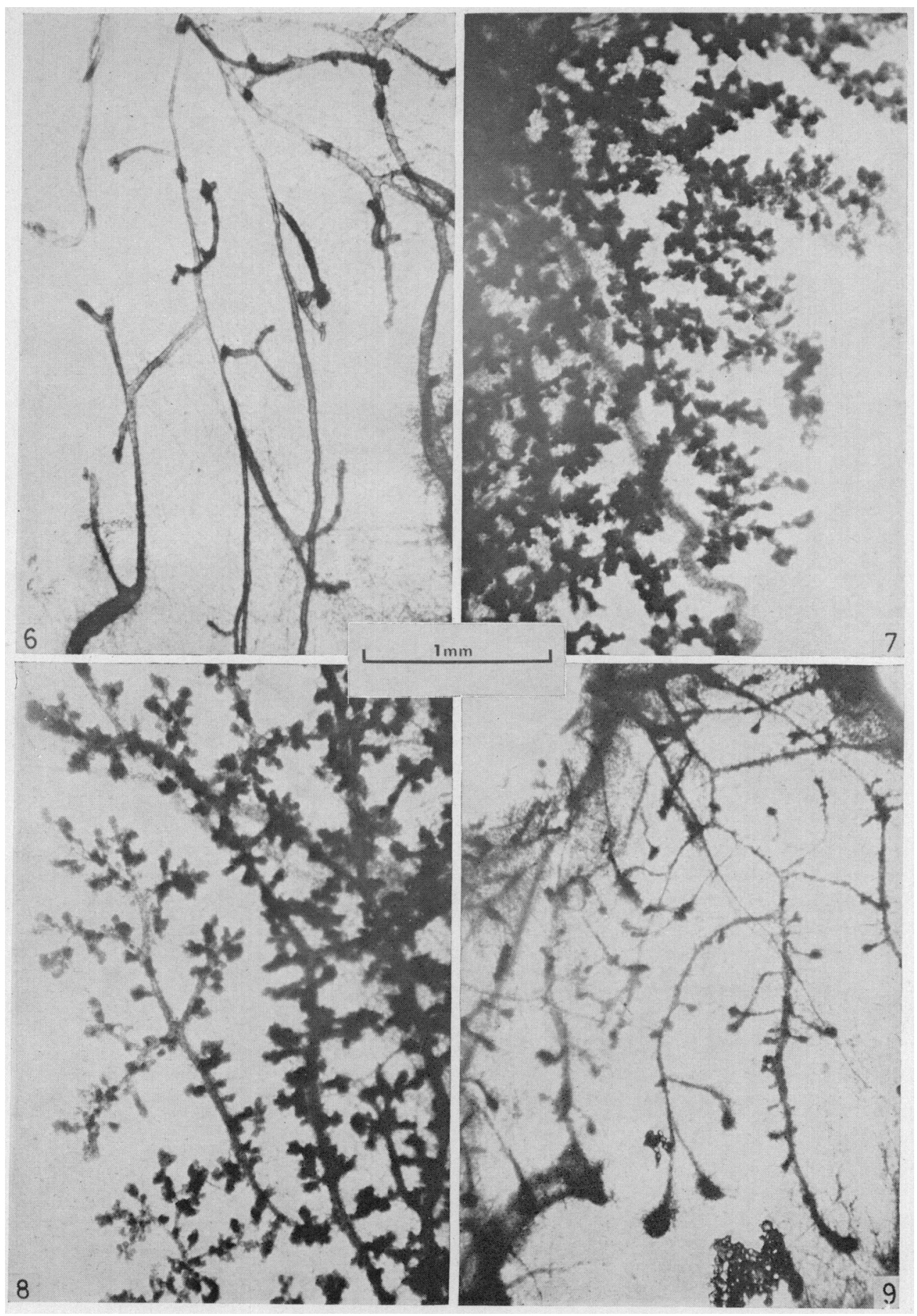




\section{Extra-uterine pregnancy in pseudopregnant hosts}

The size of the corpora lutea of pseudopregnant mice bearing an EUP did not significantly differ from those of pseudopregnant mice on which a blank operation had been performed. Moreover the presence of the EuP did not delay the onset of oestrus at the end of pseudopregnancy.

\section{The $X$-zone of the adrenal cortex}

Both adrenal glands of all but four of the thirty-eight mice bearing an EuP were histologically examined for the presence of the ' $\mathrm{X}$ ' or juxta-medullary zone. In thirty-three of the thirty-four mice this zone showed degenerative changes or had completely disappeared as it does normally midway through the first pregnancy (Howard-Miller, 1927; Deanesly, 1928). Only one mouse, bearing an EUP in the spleen, possessed adrenals with intact X-zone at the end of the experimental period (Table 1).

In contrast to these results the adrenal glands of the eleven control mice preserved a clearly defined, intact X-zone, staining conspicuously with basiphilic Biebrich scarlet.

\section{The mammary glands (see Table 2)}

Entire hosts. The mammary glands of the six entire females bearing an EUP were stimulated. They showed a marked increase in duct development (Cole, 1933), and lobulo-alveolar development equivalent to that found in the fully developed mammary gland of a pseudopregnant mouse (Pl. 2, Fig. 7). The corpora lutea of these mice were histologically indistinguishable from those of the controls. The mammary glands of the six control mice consisted only of bare ducts (Pl. 2, Fig. 6).

Ovariectomized hosts. When both ovaries were removed immediately before the transfer of the blastocysts to the kidney no stimulation of the mammary glands was detected. In a further six mice with transplanted blastocysts, ovariectomy was followed by the daily administration of $0.055 \mu \mathrm{g}$ oestrone. The blastocysts developed in four mice. Whilst this treatment caused slight growth of the mammary glands (Pl. 2, Fig. 9) the extent of development was no greater than in the ovariectomized control mice receiving only oestrone.

Adrenalectomized hosts. Blastocysts developing on the kidney of seven adrenalectomized hosts caused extensive mammary gland development in five of the mice (Pl. 2, Fig. 8). The corresponding ovaries appeared unstimulated. The

\section{EXPLANATION OF PLATE 2}

Mouse mammary glands. $\times 22$

FIG. 6. Control, recently sexually mature mouse, blank operation only. The gland consists of bare ducts.

FIG. 7. Entire host bearing an 11-day extra-uterine pregnancy. Good lobulo-alveolar development, comparable to that of normal pseudo-pregnancy.

Fig. 8. Adrenalectomized host with a 10-day extra-uterine pregnancy. Note that the absence of the adrenals has had very little effect on the development of the mammary glands.

Fig. 9. Ovariectomized host maintained on $0.055 \mu$ g oestrone/day with an 11-day extrauterine pregnancy. The mammary gland has not been stimulated. 
degree of lobulo-alveolar proliferation was equal at least to that seen in the entire mice. Adrenalectomy followed by a blank operation in five animals did not cause mammary stimulation.

Hypophysectomized hosts. In all six hypophysectomized mice, the transplanted blastocyst developed normally. The mammary glands, however, showed no sign of stimulation.

TABLE 2

TO SHOW EFFECTS OF AN EXTRA-UTERINE PREGNANGY ON THE MAMMARY GLANDS

\begin{tabular}{l|c|c|c}
\hline \multicolumn{1}{c|}{ Experiment } & $\begin{array}{c}\text { No. of } \\
\text { experiments }\end{array}$ & $\begin{array}{c}\text { No. teith } \\
\text { extra-uterine } \\
\text { pregnancies }\end{array}$ & $\begin{array}{c}\text { Mammary } \\
\text { glands } \\
\text { stimulated }\end{array}$ \\
\hline $\begin{array}{l}\text { Entire. One blastocyst transplanted to either kidney } \\
\text { Entire. 'Blank' operation (control) }\end{array}$ & 6 & 6 & 6 \\
\hline $\begin{array}{l}\text { Bilateral ovariectomy. One blastocyst transplanted to } \\
\text { either kidney }\end{array}$ & 6 & - & 0 \\
$\begin{array}{l}\text { Bilateral ovariectomy, 0.055 } \mu \mathrm{g} \text { oestrone/day. One } \\
\text { blastocyst transplanted to either kidney }\end{array}$ & 6 & 6 & 0 \\
$\begin{array}{l}\text { Bilateral ovariectomy, 0.055 } \mu \mathrm{g} \text { oestrone/day } \\
\text { (control) }\end{array}$ & 3 & - & 0 \\
\hline $\begin{array}{l}\text { Bilateral adrenalectomy. One blastocyst transplanted to } \\
\text { either kidney }\end{array}$ & 7 & - & 5 \\
\begin{tabular}{l} 
Bilateral adrenalectomy. 'Blank' operation (control) \\
\hline Hypophysectomy. One blastocyst transplanted to either \\
kidney
\end{tabular} & 6 & 6 & 0 \\
\hline
\end{tabular}

\section{DISCUSSION}

Mouse blastocysts extracted from the uterus $3 \frac{1}{2}$ days after mating were transplanted to the spleen or to the kidney of sexually mature, nulliparous females. In both sites development is initially arrested for approximately 1 to $1 \frac{1}{2}$ days due probably to transplantation shock, thereafter the conceptus develops at the normal rate.

In the present experiments the conceptus was allowed to develop for a period of 9,10 or 11 days. The developmental age of the conceptus at autopsy was therefore between 11 and 13 days. There was no significant difference in the results over this period and they will, therefore, be considered collectively. It seems legitimate to compare the results obtained with the conditions normally found at mid-pregnancy especially since the extra-uterine 'placenta' in some cases had become organized and developed to such an extent as to be very similar in morphology to a mouse placenta at mid-pregnancy (Pl. 1, Figs. 1 and 2).

By mid-pregnancy the placenta both of rats (Astwood \& Greep, 1938; Averill, Ray \& Lyons, 1950; Canivenc, 1956) and mice (Newton \& Beck, 1939) produces a luteotrophic hormone $(\mathbf{L T H})$ of which the trophoblast is considered 
to be the major source (Averill et al., 1950; Mayer \& Canivenc, 1950; Cerruti \& Lyons, 1960); this conclusion was reached from experiments in which the foetal and maternal components of the placentae were surgically separated and assayed independently. A possible criticism of this method is the likelihood that the foetal (or trophoblastic) portion was contaminated with decidual tissue, or products of decidual origin. Alloiteau (1957) has suggested that rat trophoblast begins to secrete LTH from Day 6 of pregnancy (sperm in vaginal smear-Day 0). He found that rats hypophysectomized on Day 6, and given daily progesterone, maintained pregnancy corpora lutea. In a later paper, however, (Alloiteau, 1958), he states in other rats, hypophysectomized before implantation and given progesterone as before, the placental LTH caused the active destruction of the corpora lutea.

The present experiments show that the trophoblast of an extra-uterine pregnancy did not secrete LTH in detectable amounts. The response of the ovary to LTH is characterized by a clearly marked increase in the size of the luteal cells with a corresponding overall enlargement of the corpus luteum. The ovaries of fifty-one mice bearing an EUP have been examined, and in no instance were the corpora lutea larger or different in appearance from those of the cyclic ovary (Pl. 1, Fig. 4).

Progesterone secreted in sufficient amounts by active corpora lutea will cause changes in the genital tract in association with oestrogen. The vaginal epithelium becomes mucified and ceases to show cyclic changes and the uterus passes through a stage during which it will respond to traumatic stimulation by a decidualization of the endometrium. The presence of flourishing trophoblast growth outside the uterus did not cause mucification of the vaginal epithelium. In four animals, however, the oestrous cycle was arrested, but since this also occurred in some of the control animals it was probably caused by operative trauma disturbing normal ovarian function. In the great majority of host mice the vaginal smears, after a short post-operative disturbance, showed normal cyclic changes, and traumatization of the uterus failed in every case to bring about a decidual reaction (Table 1).

Probably the most convincing demonstration that the presence of extrauterine trophoblast failed to bring about normal pregnancy changes in the host mice, is that mice bearing an established EuP would mate and conceive normally (P1. 1, Fig. 3). Hence it would seem that the trophoblast of an EUP in the mouse either does not produce a luteotrophic hormone or does so in insufficient quantities to stimulate the corpora lutea. Moreover, recent work by Bland \& Donovan (personal communication) shows that the same is probably true of the guinea-pig. An EuP in this animal does not inhibit or delay the onset of oestrus.

The above data also suggest that the trophoblast of an EuP does not secrete progesterone in quantities necessary to bring about typical progestational changes in the genital tract.

Since the model used in these experiments has failed to demonstrate the presence of LTH one is justified in suspecting that there might be a flaw in the experimental design.

First, it has been suggested that the corpora lutea of ovulation quickly 
become refractory (possibly within $24 \mathrm{hr}$ ) to the effect of LTH (Evans, Simpson \& Lyons, 1941; Astwood, 1941; Kovačic, 1963). For this reason, mice at each stage of the oestrous cycle have received blastocysts so that any trophoblast secretion might coincide with freshly formed corpora lutea.

Secondly, one might suspect that the mass of extra-uterine trophoblast is insufficient to justify comparison with a normal pregnancy. However, the amount of trophoblast which develops from a blastocyst in an extra-uterine location, especially the spleen (Kirby, 1963), is usually in excess of that which develops from an egg in the uterus. Occasionally the extra-uterine trophoblast develops into a structure very similar to that of a normal placenta (Pl. 1, Figs. 1 and 2). Moreover, although two flourishing EUP fail to stimulate the ovary, the placenta from a single blastocyst transplanted to a pseudopregnant female will maintain pregnancy quite normally (Billington, personal communication; and own observation). Insufficiency of extra-uterine placental tissue is not an adequate explanation of the negative results.

Thirdly, it may be argued that placental LTH normally exerts its effect on corpora lutea that have already been stimulated by hypophyseal LTH released shortly after coitus. To meet this criticism, blastocysts were transplanted to the kidneys of six mice that had been rendered pseudopregnant 3 days earlier (by mating with a sterile male). The resulting EuP failed to convert the corpus luteum of pseudopregnancy into the larger corpus luteum of pregnancy and the extra-uterine trophoblast did not postpone the onset of the next oestrus.

Although an EUP fails to demonstrate that LTH or progesterone is secreted by the trophoblast, it nevertheless causes changes in the adrenal cortex and mammary glands which correspond to those occurring in pregnancy and pseudopregnancy. Midway through the first pregnancy of the mouse the conspicuous juxta-medullary or X-zone of the adrenal cortex degenerates (HowardMiller, 1927; Deanesly, 1928; Chester Jones, 1952). The sequence of events which leads to circulating androgens and the disappearance of the X-zone in pregnancy remains a controversial issue. In an attempt to elucidate some aspects of the problem much experimental work, to be published separately, has been carried out. Briefly the findings fail to confirm those of Chester Jones (1952), who maintains that a luteotrophic substance, secreted by the trophoblast, stimulates the ovary to produce an androgenic substance which in turn brings about the X-zone degeneration in the adrenal. Either an EUP or ACTH injection (Deanesly, 1958) will bring about X-zone degeneration in an ovariectomized mouse which suggests that androgen derives from the zona fasciculata.

A full analysis of the cause of mammary gland stimulation in mice bearing an EUP must await the results of further investigation. However, two facts are clear (see Table 2). First, the presence of the ovary is necessary; in mice ovariectomized before receiving the transplanted blastocyst, the mammary glands did not develop. The administration of oestrone to these animals caused only a slight development of the mammary glands (Pl. 2, Fig. 9), similar to that occurring during oestrus (Cole, 1933). This suggests that the ovaries of mice bearing an EUP are not completely inactive but secrete sufficient progesterone for mammary gland development closely resembling that in normal pseudopregnancy (Cole, 1933). 
Secondly, hypophysectomy completely abolishes stimulation of the mammary gland by an EUP. This could be interpreted as indicating that the trophoblast exerts its action on the hypophysis, the secretion of which, in turn, stimulates the ovaries and thence the mammary gland. An alternative explanation, however, is that the trophoblast stimulates the mammary gland via an extra-hypophyseal route and hypophysectomy withdraws the potentiating hormones necessary for mammary gland development.

In view of the failure to demonstrate that extra-uterine growths of trophoblast secrete LTH one must consider whether decidual tissue is responsible for the placenta's undoubted luteotrophic activity. However, Kamell \& Atkinson (1948) have shown (and I have since confirmed) that in the mouse, unlike the rat, the induction of decidual tissue in the pseudopregnant uterus does not prolong pseudopregnancy. Thus one may conclude that neither the trophoblast nor decidual tissue, developing independently of one another, have a luteotrophic action, whereas, in the normal placenta, when they develop in intimate fusion, LTH is produced or stimulated. Thus, either the trophoblast induces luteotrophic activity in the decidua, the decidua induces luteotrophic activity in the trophoblast or there is mutual induction and both tissues give rise to LTH. Recent preliminary results suggest that the first possibility is the correct one.

Note added in proof: Results presented by Lichton (1965) show that trophoblast developing from the transplanted placenta did not inhibit oestrous cycling or stimulate the uterus. These findings confirm the results presented here.

\section{ACKNOWLEDGMENTS}

I am very grateful to Professor A. S. Parkes, F.R.s., and to Professor J. W. S. Pringle, F.R.S., for their continued help and interest in this work. I am indebted also to Dr J. Currey and Dr D. Billington for their helpful advice. The tedious histological preparations, which this work entailed, were expertly carried out by Mrs Caroline Allbut. To her I express particular thanks.

I gratefully acknowledge the generous financial support of the Medical Research Council.

\section{REFERENCES}

Allor'teau, J. J. (1957) Evolution normale des corps jaunes gestatifs chez la Ratte hypophysectomisée au moment de la nidation. C. R. Soc. Biol. 151, 2009.

Allorteau, J. J. (1958) Destruction active des corps jaunes chez la Ratte gestante hypophysectomisée avant la nidation. C. R. Soc. Biol. 152, 707.

Astwoon, E. B. (1941) The regulation of corpus luteum function by hypophyseal luteotrophin. Endocrinology, 28, 309.

Astwood, E. B. \& Greep, R. O. (1938) A corpus luteum stimulating substance in the rat placenta. Proc. Soc. exp. Biol. Med. 38, 713.

Averill, S. C., RAy, E. W. \& Lyons, W. R. (1950) Maintenance of pregnancy in hypophysectomised rats with placental implants. Proc. Soc. exp. Biol. Med. 75, 3.

BAKER, J. R. (1962) Experiments on the action of mordants. 2. Aluminium-haematein. Quart. F. micr. Sci. 103, 493.

Cantvenc, R. (1956) Le placenta de Rat et son activité endocrine. Archs Anat. Histol. Embryol. 39, 1.

Cerruti, R. A. \& Lyons, W. R. (1960) Mammogenic activities of the mid-gestational mouse placenta. Endocrinology, 67, 884.

Chester Jones, I. (1952) The disappearance of the X-zone of the mouse adrenal cortex during first pregnancy. Proc. R. Soc. B, 139, 398.

CoLe, H. A. (1933) The mammary gland of the mouse, during the oestrous cycle, pregnancy and lactation. Proc. R. Soc. B, 114, 136. 
Deanesly, R. (1928) A study of the adrenal cortex in the mouse and its relation to the gonads. Proc. $R$. Soc. B, 103, 523.

DeANEsLy, R. (1930) The corpora lutea of the mouse, with special reference to fat accumulation during the oestrous cycle. Proc. $R$. Soc. B, 106, 578.

DeAnesly, R. (1958) Secretion of androgens by the adrenal cortex of the mouse. Nature, Lond. 182, 262.

Evans, H. M., Simpson, M. E. \& Lyons, W. R. (1941) Influence of lactogenic preparations on production of traumatic placentoma in the rat. Proc. Soc. exp. Biol. Med. 46, 586.

FLux, D. S. (1954) Growth of the mammary duct system in intact and ovariectomised mice of the CH1 strain. F. Endocrin. 11, 223.

HowARD-Miller, E. (1927) A transitory zone in the adrenal cortex which shows age and sex relationships. Amer. F. Anat. 40, 251.

Kamell, S. A. \& Atkinson, W. B. Absence of prolongation of pseudo-pregnancy by induction of deciduomata in the mouse. Proc. Soc. exp. Biol. Med. 67, 415.

KIRBY, D. R. S. (1962) The effect of the uterine environment on the development of mouse eggs. 7. Embryol. exp. Morph. 10, 496.

Krrby, D. R. S. (1963) Development of the mouse blastocyst transplanted to the spleen. $\mathcal{F}$. Reprod. Fertil. 5, 1.

KIRBY, D. R. S. (1965) A small animal operating board with magnetically attached fasteners and retractors. F. Reprod. Fertil. 10, 467.

Kovačic, N. (1963) The deciduoma assay: a method for measuring prolactin. 7 . Endocrin. $28,45$.

Lichton, I. J. (1965) Survival and endocrine function of rat placenta implanted to the spleen. Endocrinology, 76, 1068.

Mayer, G. \& Canivenc, R. (1950) Autogreffes de placenta chez la ratte. C.R. Soc. Biol. $144,410$.

Newton, W. H. \& Beck, N. (1939) Placental activity in the mouse in the absence of the pituitary gland. 7. Endocrin. 1, 65. 